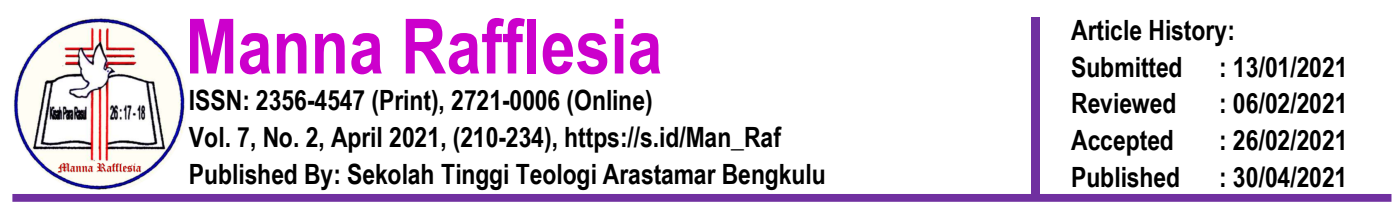

\title{
PERINTISAN GEREJA SEBAGAI BAGIAN DARI IMPLEMENTASI AMANAT AGUNG
}

\author{
Simon $\left.^{1}{ }^{*}\right)$, Semuel Ruddy Angkouw ${ }^{2}$ \\ Sekolah Tinggi Teologi Anugrah Indonesia ${ }^{1}$,Sekolah Tinggi Alkitab Batu ${ }^{2}$ \\ *) Email Correspondence: simonpetrus45144@gmail.com
}

\begin{abstract}
This paper discusses the initiation of the church as part of the implementation of the Great Commission. The method used in this paper is a qualitative method with a literature approach. Planting churches is part of the Great Commission because the pioneers of the church implement the spread of the Gospel to the established congregations. If we trace the $P B$ (New Agreement) and its historical records in determining the pioneering locations of the church, God and man played a role. From God's point of view, it is theological basis when Paul and Silas prayed, then the Holy Spirit gave instructions on where they should go (Acts 16: 4-12). While from humans, the apostles sent people to preach the Gospel in the designated areas. In this pioneering exercise in identifying culture, it requires the involvement of mentoring involved. In starting a new church planting, focus on the arrangement of faith to new converts as well as on the congregation that will join as members but take priority over discussing material matters.

Keywords: $\quad$ Planting the Church, Great Commission, Servant of God
\end{abstract}

Abstraksi: $\quad$ Tulisan ini membahas mengenai perintisan gereja sebagai bagian dari implementasi Amanat Agung. Metode yang digunakan dalam tulisan ini adalah metode kualitatif dengan pendekatan kepustakaan. Merintis gereja merupakan bagian dari Amanat Agung karena perintisan gereja mengimplementasikan penyebaran Injil kepada jemaat yang terbentuk. Jika menelusuri PB dan catatan historinya dalam menentukan lokasi perintisan gereja, Allah dan manusia berperan. Dari sisi Allah dasar teologisnya ketika Paulus dan Silas berdoa, kemudian Roh Kudus memberi petunjuk kemana mereka harus pergi (Kis. 16:412). Sementara dari sisi manusia, para rasul mengutus orang-orang untuk memberitakan Injil ke daeah-daerah yang ditetapkan. Di dalam pelaksaan perintisan gereja mengenali budaya diperlukan serta keterlibatan dari mentoring dilibatkan. Di dalam memulai penanaman gereja baru, berfokus kepada penataan iman kepada petobat-petobat baru maupun pada jemaat yang akan bergabung sebagai anggota tetap diprioritaskan dari pada membicarakan hal-hal yang bersifat materi.

Kata Kunci: $\quad$ Merintis Gereja, Amanat Agung, Hamba Tuhan

\section{PENDAHULUAN}

Indonesia People Network (IPN) telah melakukan penelitian, dari hasil penelitian menunjukkan bahwa Indonesia memiliki suku sebanyak 781. Dari jumlah suku ini, diketahui masih ada 131 suku dengan jumlah 142.000 .000 jiwa 
yang masih terabaikan atau dengan kata lain belum terlayani dalam penjangkauan Injil. ${ }^{1}$ Penyebab masih banyaknya masyarakat tanah air tidak terjangkau, sebagian organisasi gereja tidak menggalakkan gerakan perintisan gereja sebagai upaya dalam mengimplementasikan Amanat Agung. Bilangan Reserch Center mengadakan penelitian survei secara nasional kepada 4000 gembala sidang dari berbagai denominasi di 33 provinsi di Indonesia tentang pertumbuhan gereja. Ada empat aspek dari pertumbuhan gereja yang diukur, yaitu pertambahan jumlah jemaat, perintisan gereja baru, pertumbuhan kualitas iman dan melihat proses pertumbuhan gereja itu. Dari hasil penelitian yang dilakukan oleh BRC tentang peran organisasi gereja yang diwakili oleh gembala dalam penggerakan penanaman gereja baru, hanya sepertiga responden (denominasi) yang aktif menggalakkan perintisan gereja itu pun dilakukan di kota. ${ }^{2}$

Data di atas menunjukkan perintisan gereja belum sepenuhnya merata di berbagai pelosok tanah air, maka tidak mengherankan bila masih banyak sukusuku yang belum terjangkau dalam penyebaran Injil. Dengan menggerakkan penanaman gereja baru merupakan salah satu wadah dalam mengimplementasikan Amanat Agung Yesus Kristus sebelum keterangkatan-Nya ke surga. Packer mengemukakan setiap orang percaya mengemban Amanat Agung sehingga Injil menjadi pusat perhatian setiap orang yang belum percaya kepada Yesus Kristus, sehingga itu merupakan tanggung jawab yang tidak dapat diabaikan. ${ }^{3}$

1 Fransiskus Irwan Widjaja dkk., "Motif Misi Dan Pertumbuhan Gereja Masa Kini," Real Didache 3, no. 2 (2018): 23, https://doi.org/10.13140/RG.2.2.34081.63849.

2 Handi Irawan \& Bambang Budijanto, Kunci Pertumbuhan Gereja Berdasarkan Temuan Survei Nasional BRC (Jakarta: Yayasan Bilangan Research Center, 2020). http://bilanganresearch.com/hasilpenelitian.html

3 J. I. Packer, Penginjilan Dan Kedaulatan Allah Evangelism And The Sovereignty Of God (Surabaya: Momentum, 2003), 16. 
Merintis gereja dapat dimaknai dengan penanaman gereja baru dari yang tidak ada menjadi ada sampai gereja itu berdiri hingga tercipta multipkasi atau penambahan gereja. Wujud dari proses penambahan gereja baru ini dapat diibaratkan seperti benih yang ditanam, kemudian bertumbuh dan menghasilkan buah serta semakin bertambah dalam jumlah. ${ }^{4}$ Sedangkan menurut Pate merintis gereja adalah adanya pertambahan jumlah gereja demi gereja bukan sekedar pertumbuhan kenaikan angka biasa yaitu satu atau dua gereja setiap tahun, namun berlipat ganda dalam deret bilangan berpangkat dua gereja menjadi empat, empat menjadi 16 dan seterusnya. ${ }^{5}$

David Garrison mengemukakan 4 klasifikasi tentang perintisan gereja, yaitu berlipat dengan cepat, pribumi, gereja mendirikan gereja dan di dalam kelompok suku. Berlipat dengan cepat bermakna sebuah gerakan pendirian gereja berlipat ganda dalam waktu yang singkat. Sementara pribumi bermakna gerakan pendirian gereja yang dipeloporin sendiri oleh orang pribumi (dalam) tanpa keterlibatan pihak luar. Gereja mendirikan gereja adalah gerakan pendirian gereja yang ditandai dengan gereja mendirikan gereja tanpa bergantung pada gereja induk. Sementara di dalam kelompok suku dipahami sebagai gerakan pendirian gereja yang muncul di tengah-tengah kelompok atau segmen yang sama secara budaya dan bahasa. ${ }^{6}$ Dari definisi di atas merintis gereja yang dimaksud pada artikel ini adalah pembukaan gereja baru dari yang tidak ada menjadi ada, serta terjadi multipikasi secara cepat karena digerakkan oleh orang-orang di dalamnya. Segmentasi merintis gereja ditujukan kepada orang yang belum percaya maupun

\footnotetext{
4 Simon, "Peran Roh Kudus Bagi Hamba Tuhan Dalam Merintis Gereja," LOGIA: Jurnal Teologi Pentakosta 1, no. 2 (2020):41-64. https://doi.org/10.37731/log.v1i2.33

5 Larry Pate, Merintis Gereja-Gereja Baru (Malang: Gandum Mas, 1984), 30.

6 "Gerakan-gerakan Pendirian Jemaat - Perspektif: Tentang Gerakan Orang Kristen Dunia," diakses 18 Februari 2021, https://perspektif.co/Gerakan-gerakan_Pendirian_Jemaat.
} 
kepada orang yang sudah percaya namun belum dewasa secara iman serta tidak tergembalakan.

Meskipun merintis gereja di masa kini banyak kesulitan, namun tugas ini harus dilakukan sebagai bagian dari Amanat Agung. Kendala utama yang dihadapi dalam pelaksanaan perintisan gereja ialah faktor dari lingkungan serta faktor perizinan pembangunan rumah ibadah. Faktor kendala dari lingkungan, masih seringnya kita mendengar dan melihat, bagaimana sebagian gereja-gereja mengalami penolakan dan resolusi. Sebagaimana yang diungkapkan oleh Saprilla bahwa peristiwa pelarangan pendirian rumah ibadah adalah fakta yang tak terbantahkan, pembakaran atau perusakan rumah ibadah adalah fenomena peristiwa yang sering terdengar dan terlihat di tanah air. Kasus-kasus seperti ini terjadi di hampir semua wilayah di seluruh kawasan Nusantara. ${ }^{7}$ Padahal hak untuk beribadah dan mendirikan rumah ibadah merupakan bagian integral dari kebebasan beragama yang termuat dalam undang-undang. Ini dilihat bila merujuk secara teoritis, bahwa pembangunan tempat ibadah adalah hak setiap pemeluk agama. Akan tetapi pada praktiknya, masih banyak dijumpai hambatan dan halangan bagi agama Kristen dalam mendirikan rumah ibadah. ${ }^{8}$

Dari sisi perizinan adanya surat keputusan (SK) menteri agama dan menteri dalam negeri mengenai pelaksanaan tugas aparatur pemerintahan dalam menjamin ketertiban dan kelancaran pelaksanaan pengembangan dan ibadat agama oleh pemeluknya. Pada pasal 4 ayat 1 perundangan tersebut menjelaskan pendirian rumah ibadah yang baru harus mendapat izin dari kepala daerah atau

7 Saprillah Saprillah, "Rumah Ibadah Sebagai Medan Kontestasi Beragama," Harmoni 16, no. 2 (2018): 357-73, https://doi.org/10.32488/harmoni.v16i2.13.

${ }^{8}$ Siti Nurhayati Ihsan Ali-Fauzi, Samsu Rizal Panggabean, Nathanael Gratias Sumaktoyo, Anick H. T., Husni Mubarak, Testriono, Kontroversi Gereja di Jakarta (Jakarta: Universitas Gadjah Mada, 2011), 21. 
pemerintahan setempat yang memiliki wewenang perihal ini. Histori dikeluarkannya SK tersebut karena makin bertambah banyak jumlah umat Kristen diberbagai daerah dengan pesat yang menimbulkan kecemburuan bagi kelompok mayoritas, efeknya menimbulkan aksi perusakan terhadap gedung gereja. ${ }^{9}$

Sekalipun faktor lingkungan dan perizinan seakan mencoba membatasi ruang gerak untuk tidak terjadinya perintisan gereja, mengimplementasikan Amanat Agung dalam wujud penanaman gereja harus dilaksanakan. Perintisan gereja merupakan salah satu ekspansi untuk mendongkrak pertambahan jumlah pengikut Kristus. Terciptanya keberlangsungan perintisan gereja untuk tetap berjalan, organisasi gereja dan Seminari Teologi perlu mengupayakan hal ini. Organisasi gereja terbentuk tidak hanya berkecimpung pada urusan adminstrasi orgaisasi, tetapi organisasi hadir agar tidak melupakan pada visi dan misi penanaman gereja baru. Sementara Seminari Teologi tidak hanya berfokus menciptakan minat mahasiswa pada pengembangan intelektual pemahaman biblika namun menomorduakan gerakan perintisan gereja sebagai segmentasi utama dari pendidikan telogi itu sendiri. Besarnya tantangan dan hambatan dalam memulai perintisan gereja mengikis dan mengurungkan niat sebagian calon hamba Tuhan untuk melakukan pelayanan perintisan. ${ }^{10}$

Ruang lingkup pembahasan tulisan ini adalah bagaimana peran organisai gereja dan seminari dalam penyiapan tenaga perintis? Apa korelasi amanat agung dengan merintis gereja? Apa yang harus diperhatikan oleh calon hamba Tuhan bila ingin memulai merintis gereja? Ketiga pertanyaan ini akan menjadi fokus dari uraian tulisan ini. Dengan menguraikannya, ada tujuan dan manfaat yang hendak

9 Binsar A. Hutabarat, "Evaluasi Terhadap Peraturan Bersama Menteri Tahun 2006 Tentang Pendirian Rumah Ibadah," Societas Dei 4, no. 1 (2017): 9-10. https://doi.org/10.33550/sd.v4i1.41

10 Simon, "Peran Roh Kudus Bagi Hamba Tuhan Dalam Merintis Gereja," 44. 
dicapai. Adapun manfaat dari tulisan ini secara praksisinya mendorong mereka yang akan merintis gereja yang teraplikasikan dalam pelayanan.

\section{METODE}

Sugiyono menjelaskan penelitian merupakan bagian dari bentuk keilmiahan dengan tujuan memperoleh data agar berguna. Berdasarkan pengertian tersebut terdapat empat yang perlu perlu dipahami lebih lanjut yaitu: dengan cara ilmiah, data, tujuan dan kegunaannya. Penelitian merupakan cara ilmiah, berarti penelitian itu didasarkan pada ciri keilmuannya seperti rasional, empiris dan sistematis. ${ }^{11}$ Tulisan ini menggunakan metode kualitatif dengan pendekatanan studi kepustakaan. Pendekataan studi kepustakaan dipilih untuk menambah kefaktualan data-data baik dalam buku maupun jurnal. Menurut Zed pendekatan kepustakaan untuk memberikan jawaban atas topik yang diteliti dan jawaban didapatkan itu dari sumber kepustakaan menjawab pertanyaan penelitian, sebab penelitian tersebut hanya dapat dijawab melalui penelitian kepustakaan karena data penelitian yang diperoleh berasal dari sumber perpustakaan ${ }^{12}$

\section{HASIL}

Penelitian tentang perintisan gereja sebagai bagian dari Amanat Agung memberikan pemikiran tentang pentingnya peran gereja secara organisasi dan Seminari Teologi untuk menyiapkan tenaga perintisan gereja. Penelitian ini juga menghasilkan konsep pemikiran tentang korelasi Amanat Agung dalam perintisan gereja. Selanjutnya penelitian ini juga memberikan kebaruaan secara khusus dalam untuk hal-hal yang perlu diperhatikan dalam perintisan gereja, agar 
semakin bertambah secara kuantitas jumlah orang percaya diperlukan hambahamba Tuhan yang bersedia merintis gereja. Dengan mereka merintis gereja, menentukan area di mana gereja akan dirintis melalui petunjuk Tuhan atau melalui pendelegasian sebagaimana yang diperbuat oleh para rasul mengutus orang-orang ke daerah-daerah untuk mendirikan gereja lojal. Setelah menetukan tempat, langkah selanjutnya mengenali kultur geografi, budaya, sosial perlu diperhatikan dalam memulai penanaman gereja baru. Dengan melakukan hal ini ia menyadari bahwa tugasnya merintis gereja berfokus kepada pembinaan iman petobat baru, bukan kepada material. Agar hamba Tuhan itu tetap berfokus pada perintisan gereja yang dilakukan, ia memerlukan mentoring atau bapak rohani sebagai mentoring sekaligus rekan dalam menata gereja yang baru dirintis.

\section{PEMBAHASAN}

Penulis akan menjelaskan hasil dari penelitian, yaitu mengenai peran organisasi gereja dan Seminari Teologi dalam menyiapkan sumber daya perintis, korelasi Amanat Agung dan perintisan gereja dan hal-hal penting yang perlu diperhatikan dalam melaksanakan perintisan gereja.

\section{Peran Organisai Gereja Dan Seminari Teologi Dalam Penyiapan Tenaga Perintis}

Gereja memiliki dua tujuan yang tidak dapat dikesampingkan, yaitu melayani tubuh Kristus dan tersebar untuk melayani dunia. ${ }^{13}$ Organisasi gereja dan Seminari Teologi perlu berkolaborasi dan berkontribusi untuk terlibat dalam perintisan gereja. Organisasi gereja didesain tidak hanya berfokus pada masalahmasalah administrasi, tetapi perlu tetap mempersiapkan tenaga-tenaga calon

13 Paul Enns, The Moody Hanbook Of Theology (Malang: SAAT, 2010), 354. 
perintis dalam pembukaan gereja baru. Begitu juga dengan Seminari Teologi, tidak hanya meluluskan para mahasiswa berintelektual tinggi dalam pemahaman biblika, tetapi juga berusaha membina mahasiwa untuk bisa membuka perintisan gereja baru. Albert Konaniah menyatakan sebagian mahasiswa institusi teologi hanya mampu menggembalakan gereja yang sudah ada, tetapi peserta didiknya tidak mampu melakukan penginjilan dan memulai perintisan gereja. ${ }^{14}$

Gereja dan Seminari Teologi perlu mencanangkan agar para calon hamba Tuhan memiliki ketertarikan dalam merintis gereja dan menjadikan hal tersebut visi dan misi utama. Kontribusi organisasi gereja yang bisa dilakukan adalah, mewujudkan pembukaan gereja baru sebagai kerangka kerja utama dalam penambahan jumlah gerja baru yang berdiri. Made Nopen Supriadi menemukakan salah satu wujud pelayanan misi yang hendak dikerjakan gereja adalah menjangkau orang-orang terabaikan dalam pelayanan Injil. Pelayanan ini dapat dilakukan dengan melibatkan tenaga-tenaga dari lulusan Sekolah Teologi. Bila gereja melibatkan para mahasiswa teologi untuk merintis gereja maka dapat menciptakan pembukaan pos-pos pelayanan baru. ${ }^{15}$ Bila bercermin dari gereja mula-mula para pemimpin menyiapkan orang-orang untuk dikirim dalam pembukaan gereja baru. Pate mengemukakan Gereja di zaman Perjanjian Baru mengutus orang-orang yang terpanggil untuk menginjili ke berbagai daerah. Walaupun menjadi tanggung jawab setiap orang percaya untuk bersaksi dalam masyarakatnya sendiri, namun memang ada orang yang bekemampuan dan dipanggil pergi ke daerah baru. Contoh gereja di Anthiokia, Paulus dan Barnabas

\footnotetext{
${ }^{14}$ Albert Konaniah, "Sekolah Teologi Dan Gerakan Penginjilan," Veritas: Jurnal Teologi dan Pelayanan 3, no. 2 (2002): 221. https://doi.org/10.36421/veritas.v3i2.94

15 Made Nopen Supriadi, "Implikasi Relasi Sekolah Tinggi Teologi Arastamar Bengkulu Bagi Pengembangan Pelayanan Misi Gereja Kristen Injili Di Indonesia Jemaat Kota Bengkulu," Jurnal PKM Setiadharma 1, no. 2 (2020): 1-12. https://doi.org/10.47457/jps.v1i2.54
} 
diutus hingga tercipta penanaman gereja baru. (Kis. 13: 1-3). ${ }^{16}$ Organisasi gereja juga perlu memberikan jaminan biaya hidup bagi calon hamba Tuhan yang bersedia merintis gereja. Saputra menyatakan kemajuan pelayanan misi akan tercipta bila organisasi gereja menjalankan pelayanan diakonia. ${ }^{17}$ Hal tersebut perlu dilakukan karena salah satu tantangan dalam merintis gereja adalah terbatasnya keuangan hamba Tuhan dalam memulai pembukaan gereja baru. Oleh sebab itu, organisasi gereja perlu memberikan jaminan kecukupan biaya hidup bagi calon hamba Tuhan yang ingin merintis gereja. Hamba Tuhan yang hendak merintis gereja memerlukan dukungan materi agar mampu survive (bertahan) di lapangan, karena tidak cukup hanya dengan bermodalkan keberanian, niat dan kekuatan spiritual, namun perlu dukungan finansial agar para perintis tidak goyah, bahkan mundur karena kekurangan sandang pangan. ${ }^{18}$

Seminari Teologi perlu berkontribusi agar tercipta gerakan perintisan gereja dengan mendorong para mahasiswa bahwa segmentasi utama pelayanan yang akan digeluti adalah pembukaan gereja baru. Penulis mengamati kecenderungan banyak Sarjana Teologi ketika selesai studi sedikit yang memiliki fokus untuk merintis gereja, kecenderungan banyak yang beralih untuk menjadi Pegawai Negeri Sipil (PNS) Pendidikan Agama Kristen, melanjutkan jenjang studi lebih tinggi untuk menjadi dosen atau menjadi gembala sidang yang sudah ada gereja dan bekerja di instansi swasta atau pemerintah. ${ }^{19}$ Hal itu bukankah sebuah kesalahan, akan tetapi jika itu menjadi siklus yang diperbuat oleh setiap

\footnotetext{
${ }^{16}$ Larry Pate, Merintis Gereja-Gereja Baru.

${ }^{17}$ Agustina Rombe, "Pengaruh Pelayanan Diakonia terhadap Pertumbuhan Gereja Toraja Jemaat Sudiang Makassar" (Sekolah Tinggi Theologia Jaffray, 2018), 37.

18 Simon, "Peran Roh Kudus Bagi Hamba Tuhan Dalam Merintis Gereja," 58.

19 Penilaian ini berangkat dari salah satu institusi seminari teologi yang penulis ketahui, mulai tahun 2010-2020 mahasiwa yang lulus berjumlah kurang lebih 150 orang. Dari jumlah tersebut tidak ada sepertiga yang merintis gereja.
} 
lulusan Sarjana Teologi, maka hal itu dapat menyebabkan sedikitnya tercipta pembukaan gereja-gereja baru. Mengenai hal tersebut Konaniah menuliskan:

Tidak sedikit pendidikan teologi saat ini bukannya membantu perkembangan penginjilan dan mempertumbuhkan gereja, tetapi justru menjadi penghalang pekerjaan penginjilan. Karena itu, bagi mereka yang berkiprah dalam pendidikan teologi seharusnya bertanya: Apakah tugas utama dari Sekolah Teologi? Apakah Sekolah Teologi hanya berupaya membentuk kehidupan spiritual seseorang? Sudah cukupkah jika Sekolah Teologi hanya sekadar memberikan informasi perkembangan teologi terkini? Apakah Sekolah Teologi hanya ingin membangun suatu teologi sendiri? Apakah hanya sekadar hendak mencetak teolog-teolog zaman ini, atau memperlengkapi hamba Tuhan dan gereja untuk menunaikan amanat yang Tuhan berikan? Hanya pendidikan teologi yang berpusat pada Amanat Agung Tuhan Yesus-lah yang dapat berjalan seiring dengan pekerjaan penginjilan dunia. ${ }^{20}$

Selanjutnya ada beberapa hal yang menyebabkan belum terlalu tinggi ketertarikan lulusan teologi untuk merintis gereja. Pertama, dapat dilihat dari tidak adanya secara spesifik kurikulum atau pembahasan mata kuliah akan pembukaan atau perintisan gereja baru. Ini penting karena kurikulum menjadi pintu apa yang akan dicapai oleh institusi. Kurikulum juga mendesain agar tercipta proses pengelolaan pembelajaran menjadi teratur serta berkualitas. ${ }^{21}$ Kedua, adanya dijumpai institusi seminari tidak menjadikan perintisan gereja sebagai visi dan misi keutamaan yang ingin dicapai oleh institusi tersebut. Ketiga, pengaruh dosen pengajarnya tidak memiliki latar belakang sebagai perintis gereja, sehingga para dosen kurang mendorong mahasiswa untuk merintis gereja. Keempat, seminari-seminari teologi mendasarkan nilai institusinya dari hasil akreditasi pemerintah. Seminari teologi didirikan sebagai wadah untuk mempersiapkan para calon hamba Tuhan dalam merintis gereja, agar penyebarluasan berita Amanat Agung menggema di segala penjuru, maka

20 albert Konaniah, "Sekolah Teologi Dan Gerakan Penginjilan," 222-23.

${ }^{21}$ Tiur Imeldawati, "Manajemen Perguruan Tinggi Teologi," Jurnal Teologi dan Pendidikan Agama Kristen 1, no. 1 (2019): 69. 
Perguruan Tinggi Teologi memiliki tanggung jawab dalam mengelola semua aspek yang diperlukan untuk menghasilkan para lulusan yang berkualitas. ${ }^{22} \mathrm{Hal}$ ini pula yang disoroti oleh Risakotta bahwa Pendidikan Teologi di Indonesia masih lebih dominan berfokus pada isi kurikulum yang mengedepankan perihal bahasa Yunani, Ibrani, tentang ilmu sosial, bagaimana teologi menjadi kontekstual, seperti apa teori hermeneutik yang ideal, bagaimana menyesuaikan isi teologi Kristen dengan adat dan budaya serta sejauh mana sejarah gereja barat dengan Indonesia ke-samaannya. ${ }^{23}$ Jika seminari teologi berfokus dan mendorong lulusannya untuk pembukaan gereja-gereja baru, maka pertumbuhan gereja secara kuantitas akan mengalami lonjakan yang signifikan. Nyatanya pertumbuhan gereja secara kuantitas tidaklah signifikan. Ini diketahui menurut data yang di keluarkan Bilangan Research Centre (BRC) yang melakukan studi komparatif lintas gereja di Indonesia, terhadap 4.934 Pendeta Di 34 Kabupaten/Kota yang dilakukan oleh lembaga Pengkajian BRC tahun 2018, terkait perkembangan gereja di Indonesia saat ini, ternyata tidak terlalu pesat, jauh dari apa yang disebut sebagai ledakan pertumbuhan. Kebanyakan pertumbuhan gereja di Indonesia lebih merupakan pindahan atau migrasi dari jemaat gereja lain (42.3\%) dan pertumbuhan biologis $(28.1 \%)$. Sedangkan pertumbuhan jemaat dari hasil "penginjilan" hanya $2.1 \%$, artinya tidak ada pertumbuhan signifikan. ${ }^{24}$

Anthony mengemukakan merekrut dan membentuk pemimpin yang berkualitas untuk pengembangan bagi pendidikan Kristen telah menjadi perhatian bagi gereja kontemporer masa kini. Walau perekrutan pemimpin telah menjadi

\footnotetext{
22 Imeldawati, "Manajemen Perguruan Tinggi Teologi."

23 Bernard Adeney-Risakotta, "Mengkritisi Peran Pendidikan Teologia Dalam Pengembangan Teologi Protestan Di Indonesia," Gema Teologi 3, no. 1 (2009): 1.

${ }^{24}$ Daniel Ginting \& Sabar Manahan Hutagalu Fransiskus Irwan Widjaja, "Teologi Misi sebagai Teologi Amanat Agung," Thronos 1, no. 1 (2019): 20.
} 
bahan pemikiran, namun tetap sulit bagi gereja untuk memotivasi jemaat agar mengajukan diri secara sukarela dalam pelayaan kekristenan. ${ }^{25}$ Dengan demikian organisasi gereja dan Seminari Teologi merupakan penggerak utama dalam percepatan pertambahan gereja baru. Seminari Teologi berfungsi melengkapi keilmuan biblika dan churh planting, sementara organisasi gereja mengkaderisasi calon hamba Tuhan dalam mempersiapkan merintis disertai dukungan finansial. Jika keduanya saling bersinergi, maka makin banyak tenaga perintis gereja untuk penyebaran berita Amanat Agung. Sebab itu ukuran pertumbuhan gereja sematamata tidak hanya dilihat dari jumlah kehadiran pengunjung di setiap ibadah atau jumlah jemaat yang dibaptis, akan tetapi kategori dari pertumbuhan gereja yang lengkap bila dilihat dari pertumbuhan spiritualitas jemaat, pertumbuhan ekspansif berupa perintisan gereja yang baru serta pertumbuhan membangun jembatan dari kebudayaan di luar gereja tersebut. ${ }^{26}$

\section{Korelasi Amanat Agung Dengan Merintis Gereja}

Ada tiga hal mendasar penekanan utama dalam perintah Amanat Agung yaitu pergi memberitakan injil, membaptis yang percaya dan mengajar orang percaya untuk melakukan yang diperintahkan oleh Yesus. Pesan Amanat Agung ini menjadi kewajiban yang dilakukan oleh para rasul dalam kitab Kisah Para Rasul. Pendapat senada dikemukakan oleh Warren bahwa setiap orang Kristen adalah duta atau saksi bagi Kristus. Kemanapun orang Kristen pergi, sudah menjadi tanggung jawabnya untuk bersaksi bahwa Kristus datang ke dalam dunia, Ia telah mati di atas kayu salib, Ia telah bangkit dan berjanji akan datang kembali

25 Michael J. Anthony, Foundaion Of Mnistry An Introduction Christian Education For A New Generation, ed. oleh Christian A Tomatala (Malang: Gandum Mas, 2012).

${ }^{26}$ Djeffry Hidajat, "Sejarah dan Perkembangannya Masa Kini dan Arah Masa Depan," Jurnal Amanat Agung, t.t., 87. 
untuk kedua kali. Karena suatu saat nanti, orang percaya akan mempertanggungjawabkan di hadapan Tuhan tentang seberapa seriuskah ia memberitakan Injil. ${ }^{27}$ Para murid menghidupi pesan Amanat Agung, hal tersebut ditandai dengan semakin bertambahnya secara kuantitas pengikut Kristus (Kis. 5: 14; 6: 1). Bila dilakukan penyelidikan secara historis bertambahnya para pengikut Kristus dipenuhi oleh pergolakan dan kepedihan. Mereka diperhadapkan dengan masa yang sukar, namun dari masa yang sukar itu mereka merumuskan iman dan memproklamirkan iman itu, dan mendirikan kumpulan orang percaya di dalam dan di luar tanah Israel. ${ }^{28}$

Para pengikut Kristus memilih untuk lebih takut kepada Allah dibandingkan kepada manusia walaupun intimidasi dan ancaman mereka terima agar tidak memberitakan Amanat Agung (Kis. 5: 29-30). Upaya yang dilakukan oleh para rasul dan para Bapa gereja menunjukkan pentingnya pemberitaan Amanat Agung menjadi warisan bagi orang percaya masa kini untuk melanjutkan tongkat estafet pemberitaan Amanat Agung. Bila dalam penyebaran Amanat Agung diperintahkan untuk pergi memberitakan injil, membaptis dan mengajar, maka dalam perintisan gereja dilakukan hal yang sama. Hamba Tuhan yang merintis gereja perlu pergi ke suatu daerah yang menjadi visinya, setelah itu melakukan pendekatan personal kepada orang-orang, kemudian memberitakan Injil dan membentuk komunitas orang percaya yang nantinya menjadi cikal bakal terbentuknya gereja baru. Hal tersebut sejalan dengan pola yang dilakukan oleh para Rasul dalam Perjanjian Baru. Peter mengemukakan prinsip pendelegasian wewenang sangat dikenal dalam Alkitab. Kristus melakukan pendelegasian

${ }^{27}$ Rick Warren, The Purpose Driven Church, Gereja yang digerakkan oleh Tujuan (Malang: Gandum Mas, 2001), 104.

28 Paul Barnett, The Birth of Christianity, ed. oleh M Rumkeny, I (Malang: Gandum Mas, 2012), 51. 
kepada para murid dan para murid mendelegasikan berbagai pelayanan kepada orang lain (Mat. 10: 1; Mrk. 3: 13-15; Kis. 6: 6). ${ }^{29}$ Bila Amanat Agung menjadi keharusan mutlak yang harus dilakukan oleh setiap pengikut Kristus, maka pendirian gereja baru perlu diupayakan oleh setiap orang percaya. Dengan merintis gereja baru itu salah satu wujud mengimplementasikan perintah Yesus Kristus dalam konteks yang berbeda dan bertujuan pada rencana Allah dalam penjangkauan jiwa. ${ }^{30}$ Silitonga menuliskan sekalipun tantangan dari luar bergejolak, sudah semestinya gereja sehati sepikir bahkan makin militan menginjili dan mengajarkan firman Allah baik melalui ritual kegamaan, pemuridan dan juga pengayaan iman secara pribadi dan institusional. ${ }^{31}$

\section{Hal-Hal Yang Diperhatikan Dalam Perintisan Gereja}

Perintisan gereja perlu memperhatikan hal-hal penting berikut ini, yaitu menentukan wilayah perintisan gereja baru, mengenal budaya ditempat perintisan, perlunya mentoring dalam perintisan dan tidak berfokus pada materi.

\section{Menentukan Wilayah Perintisan Gereja Baru}

Hamba Tuhan yang hendak merintis gereja perlu menentukan area atau tempat yang hendak dituju dalam pembukaan gereja baru, dengan menentukan tempat perintisan gereja untuk digumuli dalam doa. Langkah ini sama dengan Paulus dan Silas sebelum memulai pendirian jemaat baru, terlebih dahulu menentukan tempat yang akan dituju, mendoakan dan Roh Kudus memerintahkan pergi. Dalam menentukan tempat yang akan dituju untuk perintisan gereja, hendaknya lokasi yang dituju membutuhkan keberadaan penanam gereja baru.

29 George W. Peters, A Biblical Theology of Missions, 1 ed. (Malang: Gandum Mas, 2006), 275.

30 Simon, "Peran Roh Kudus Bagi Hamba Tuhan Dalam Merintis Gereja," 48. (2018): 71

${ }^{31}$ Roedy Silitonga, "Amanat Agung Dan Kemajemukan Agama: Suatu Refleksi," Stulos 16, no. 1 
Prinsip ini sejalan dengan rasul Paulus yang memberitakan Injil hingga mendirikan gereja baru di tempat orang belum memberitakan injil (2Kor. 10: 1316). Mills menyatakan sudah selayaknya gereja dirintis di lokasi dimana Allah menaruh kerinduan di hati hamba-Nya. Gereja baru perlu dirintis di desa, pelosok dan betapa perlunya perintisan gereja-gereja ditempat belum ada gereja. Pada masa kini kecendrungan penanaman gereja baru dilakukan di wilayah yang segala sesuatu telah tersedia. Oleh sebab itu gairah dan komitmen untuk memenangkan jiwa dan perintisan gereja perlu kembali ke dalam gereja dan mempersiapkan generasi muda untuk melakukannya. ${ }^{32} \mathrm{Di}$ dalam menentukan wilayah perintisan gereja perlu memprioritaskan tempat yang membutuhkan kehadiran gereja. Waren mengemukakan agar penginjilan mencapai tujuan maka hamba Tuhan perlu bertindak dengan menelusuri segala informasi yang berkaitan dengan masyarakat yang menjadi fokus perintisan. Maka gereja perlu menetapkan target dalam empat cara yang khusus, yakni: geografis, demografis, budaya dan rohani. ${ }^{33}$

Merintis gereja memang baik, tetapi jika perintisan dilakukan pada lokasi yang sudah banyak gereja, tentu hal ini kurang optimal karena segmentasi merintis gereja adalah di tempat yang belum terjangkau. Gereja sudah berdiri 2000 tahun lebih tetapi Amanat Agung belum sepenuhya tersebar diberbagai pelosok. Ini dikarenakan sinode dan badan misi belum bekerja sama dengan semestinya. Penulis mengamati beberapa daerah seperti Jakarta, Bandung, Surabaya dan Pulau Batam, terdapat banyak gereja, selanjutnya terjadi perebutan jemaat. Banyak sinode melakukan perintisan gereja di kota dengan alasan untuk melayani jiwa-jiwa, namun pada umumnya sinode merintis gereja di kota House, 2014)

32 Dag Heward Mills, Perintis Gereja, ed. oleh Daniel Benjamin Saragih, E-BOOKS (Parchment ${ }^{33}$ Rick Warren, The Purpose Driven Church (Malang: Gandum Mas, 2004), 174. 
orientasinya lebih kepada uang, prestasi dan prestise, demi pengembangan kerajaan pribadi dan denominasi masing-masing. ${ }^{34}$ Karena itulah tugas utama dan terpenting gereja tidak boleh bergeser yaitu mengkomunikasikan kabar baik secara kontiniutas untuk membawa orang-orang mengenal Kristus sebagai Juruselamat. ${ }^{35}$ Hal tersebut dapat dilaksanakan melalui perintisan gereja yang bertujuan membina petobat baru dan mereka yang tidak tergembalakan sebagai jemaat.

\section{Mengenal Budaya Dimana Gereja Dirintis}

Budaya atau kebudayaan dapat dimaknai secara sederhana yaitu nilai-nilai atau aturan yang disepakati oleh sebuah komunitas masyarakat untuk ditaati walau aturan yang disepakati tidak tertulis secara baku dan dijadikan sebagai pegangan hidup secara berkelompok. Umanailo menyatakan kultur atau adat-istiadat yang berlaku dalam suatu kelompok masyarakat merupakan pegangan atau berfungsi sebagai pengatur dalam penataan moralitas, karakter dan prilaku manusia yang menghasilkan kehidupan yang tertib dan teratur. ${ }^{36}$ Mengenal budaya di tempat perintisan adalah strategi hamba Tuhan dalam memulai perintisan gereja, hal itu bertujuan agar dapat beradaptasi dengan lingkungan dan mampu memaknai nilainilai kebudayaan setempat. Mengenali budaya setempat dapat dilakukan dengan mempelajari dari berbagai literatur, keaktifan diri di lingkungan, terlibat dalam berbagai kegiatan dan menjalin relasi kepada masyarakat melalui pembauran diri.

Mengenali budaya setempat di mana gereja akan di rintis, akan memudahkan pemberitaan injil dan penjangkaun jiwa baru di daerah di mana

34 Yan Antoni, "Amanat Agung Belum Selesai Matius 28:18-20; Lukas 24:46-47," Jurnal Amanat Agung 7, no. 1 (2011): 146.

${ }^{35}$ George W. Peters, A Biblical Theology of Missions, 256.

${ }^{36}$ M Chairul Basrun Umanailo, IImu Sosial Budaya Dasar (Jakarta: Fam Publishing, 2015), 37. 
gereja baru akan dirintis. Samuel Purdaryanto mengemukakan usaha Paulus untuk menjangkau orang-orang non-Yahudi atau bangsa lain terlihat dalam salah satu ungkapannya yang terdapat dalam (1Kor. 9: 20). Ungkapan "menjadi seperti" menunjukan Paulus berkontekstual pada kebudayaan setempat agar dapat memenangkan etnis tersebut. Yesus pun menerapkan pola ini dengan menjadi sama dengan manusia untuk menyelamatkan umat-Nya. ${ }^{37}$ Apa yang dikemukakan oleh rasul Paulus menunjukkan betapa penting mengenali budaya serta menyatu dengan budaya dalam perintisan. Walau Paulus bebas dan tidak terikat kepada norma-norma atau adat kebiasaan dan tidak melanggar asas, namun hal itu dilakukan dengan tujuan membawa petobat-petobat bagi Kristus. Paulus menyesuaikan diri baik kepada orang Yahudi maupun non-Yahudi atau kepada orang yang dianggap kafir sekalipun, dengan tidak melanggar batas-batas kebenaran firman Allah sejauh itu untuk membawa mereka kepada Krstus. ${ }^{38}$ Dengan mengenali budaya setempat maka perintisan tetap menjaga agar tidak menabrak norma-norma yang berlaku. Dengan mengenali budaya setempat hamba Tuhan dapat menggunakan menerapkan metode yang tepat dalam pelaksanaan Amanat Agung di lingkungan baru atau lingkungan yang multikultural.

Lingkungan yang majemuk merupakan realitas objektif masyarakat Indonesia yang mengakibatkan masyarakat Indonesia menjadi masyarakat yang plural dari segi budaya, etnis, ras, bahasa dan agama, sehingga dapat disebutkan sebagai masyarakat "multi-kultur-poli-etnik". Dalam konteks masyarakat Indonesia yang plural itulah gereja hadir dan bermisi. Dalam konteks demikian

\footnotetext{
37 Samuel Purdaryanto, "Strategi Melayani Unreached People Groups Berdasarkan Kajian Eksegetis 1Korintus 9: 19-23," Manna Rafflesia 6, no. 2 (2020): 180. https://doi.org/10.38091/man_raf.v6i2.122

38 Donald Guthrie, Tafsiran Alkitab Masa Kini 3 Matius-Wahyu, ed. oleh A. Simanjuntak, 12 ed. (Jakarta: Yayasan Komunikasi Bina Kasih/OMF, 2001), 497.
} 
penting bagi gereja dalam menjalankan misinya, memilik kesadaran konteks pluralitas itu sehingga misi gereja menjadi relevan dan kontekstual. ${ }^{39}$ Dengan mengenali budaya setempat, hamba Tuhan menunjukkan kesungguhan dan kesiapan dalam merintis gereja untuk merealisasikan Amanat Agung melalui pembukaan gereja baru.

\section{Perlunya Mentoring Dalam Perintisan Gereja}

Prihanto menuliskan mentoring dapat dimaknai sebagai upaya untuk menumbuh kembangkan kapasitas diri dalam melayani agar tecipta pembelajaran yang akomodatif bagi hubungan antara individu atau sesama agar lebih peduli serta berbagi pengalaman dan pengetahuan serta sikap yang bijaksana kepada orang lain. ${ }^{40}$ Hamba Tuhan yang merintis gereja, memerlukan peran mentor agar menerima saran dan masukan dalam memulai pendirian gereja baru. Keterlibatan mentor bagi hamba Tuhan yang memulai perintisan gereja baru untuk memantau keberadaan hamba Tuhan yang merints gereja.

Pelaksana mentoring hamba Tuhan yang merintis gereja, hendaknya seorang yang telah pengalaman dalam perintisan gereja. Hal ini dimaksudkan agar ketika mementoring hamba Tuhan yang sedang merintis gereja, pengalaman dalam memulai perintisan gereja dapat ditularkan kepada yang dimentoring sehingga menjadi khasanah bagi hamba Tuhan yang merintis. Paulus pun mementoring Timotius dalam pelayanan, sehingga Timotius menjadi gembala bagi jemaat di Efesus karena peran mentoring yang dilakukan oleh Paulus (2Tim. 2: 2). Yesus dalam pelayanan selama tiga setengah tahun di bumi telah berkhotbah

39 Eklepinus Jefry Sopacuaperu, "Misi Rekonsiliasi Dalam Konteks Kemajemukan Agama Di Indonesia (Analisis Naratif Yohanes 20:19-23 dan Implikasi Misiologisnya)," Kenosis 6, no. 1 (2020): 77. https://doi.org/10.37196/kenosis.v6i1.85

40 Agus Prihanto, "Peran Proses Mentoring Pemimpin Kaum Muda Bagi Perkembangan Pelayanan Pemuda Di Gereja," Jurnal Jaffray 16, no. 2 (2018): 99. http://dx.doi.org/10.25278/jj71.v16i2.258 
kepada ribuan orang dan menyembuhkan segala sakit penyakit, namun tetap saja hanya memilih dan mendidik dua belas murid untuk memimpin gereja yang baru dan mementoring mereka untuk menjadi pemimpin. ${ }^{41}$ Sebab itu Yesus telah memberikan teladan kepada para Murid agar mereka juga berbuat sama seperti yang telah diperbuat Yesus (Yoh. 13: 15). Proses mementoring merupakan perintah dari Tuhan Yesus yang wajib kita kerjakan. Perintah ini bukan hanya sekadar diucapkan oleh Tuhan Yesus, tetapi Ia juga memberikan teladan untuk melakukan proses pemuridan. ${ }^{42}$ Peran mentoring ini tidak hanya hamba Tuhan diajari memulai pelayanan perintisan gereja, tetapi seorang mentoring menjadi "bapa rohani" bagi hamba Tuhan yang merintis gereja. Istilah bapa rohani difungsikan sebagai pendorong semangat bagi hamba Tuhan yang dimentoring, menjadi tempat sharing pada waktu mengalami kesusahan dalam pelayanan serta pemberi masukan.

Dengan demikian mentoring bagi hamba Tuhan yang ingin merintis gereja adalah hal penting untuk menolong dan memantau hamba Tuhan agar tidak goyah dan mundur dalam merintis gereja. Selain itu dengan adanya mentoring membantu hamba Tuhan dalam meningkatkan kapasitas diri dalam pelayanan perintisan gereja. Mentoring juga sebagai perekat untuk berelasi antara mentor dan mentee (yang memberi arahan / bimbingan). Karena itu mentoring merupakan suatu hubungan interpersonal dalam bentuk kepedulian atau empati antara seorang yang

\footnotetext{
41 Larry Pate, Merintis Gereja-Gereja Baru.

42 Prihanto, "Peran Proses Mentoring Pemimpin Kaum Muda Bagi Perkembangan Pelayanan Pemuda Di Gereja."
} 
memiliki pengalaman serta berpengetahuan luas dengan seorang yang kurang berpengalaman ataupun yang pengetahuannya masih sedikit. ${ }^{43}$

\section{Tidak Berfokus Pada Materi}

Hamba Tuhan yang hendak memulai pembukaan gereja baru, sebaiknya tidak mengedepankan pengadaan kolekte ketika merintis gereja. Sebab, dasar dari perintisan gereja bukan untuk pengadaan kolekte, tetapi dasar dari pendirian gereja baru adalah mendidik dan mengajarkan petobat baru dan jemaat yang tidak tergembalakan untuk semakin memahami kebenaran firman Allah. Tidak berfokus pada materi ketika memulai pembukaan gereja baru, upaya untuk menghindari agar jemaat-jemaat yang baru tergembalakan itu tidak terhalang niat untuk beribadah. Penulis melakukan wawancara dengan responden $\mathrm{DH}$, dari pengalamannya memulai perintisan gereja baru, selama tujuh tahun memulai pembukaan gereja baru tidak mengadakan kolekte saat ibadah berjalan. Bukan hanya kolekte, membahas yang sifatnya mengarah kepada materi tidak pernah lakukan di dalam memulai perintisan gereja baru. Responden mengemukakan di dalam memulai perintisan gereja baru, berfokus mendidik petobat baru dan jemaat merupakan yang harus dilakukan agar iman terbina dan kokoh karena sudah meletakkan fondasi yang kuat. Seiring bergulirnya waktu, maka jemaat-jemaat yang terbina akan berinisiatif sendiri untuk mengembangkan manajerial gereja lokal yang tertata dan terstruktur dengan rapi. ${ }^{44}$

Esensi utama setelah terbentuknya komunitas orang percaya yang nantinya menjadi cikal bakal gereja baru berdiri adalah mendidik dan mengajari jemaat

\footnotetext{
43 Nikodemus Thomas Martoredjo, "Peran Dimensi Mentoring Dalam Upaya Peningkatan Kualitas Sumber Daya Manusia," Humaniora 6, no. 4 (2015): 448. https://doi.org/10.21512/humaniora.v6i4.3373

44 Wawancara dengan Responden $\mathrm{DH}$ seorang gembala sidang yang memulai perintisan gereja dari yang tidak ada jemaat hingga menjadi ratusan. D H, Perintisan Gereja, 15 Februari 2021.
} 
agar mereka sebagai umat Tuhan yang bertumbuh dan militan sebagai pengikut Kristus. Kesampingkan membahas seperti honor pengkhotbah, properti, atau proyek pembangunan gedung ibadah. Pada umumnya jemaat yang baru dirintis kedewasaan secara rohani dalam memberi belum sepenuhnya mereka pahami. Oleh sebab itu, seorang pendeta perlu secara seksama memperhatikan dirinya dan keluarganya agar memiliki sikap yang bijaksana serta memperhatikan bagaimana ia menampikan gaya hidup di hadapan jemaat. Jadilah teladan di hadapan jemaat dalam menampilkan cara hidup berdasarkan firman Allah. ${ }^{45}$

Rasul Paulus memberikan teladan yang baik ketika merintis gereja tidak membebankan materi kepada jemaat yang dirintis. Paulus hanya berfokus pada penyebaran injil agar semakin banyak bertambah secar kuantitas orang-orang yang percaya kepada Kristus. Paulus bekerja agar pelayanan pemberitaan Injil dapat tersebar di belahan benua Eropa dan Asia. Paulus berkata kepada jemaat Tesalonika bagaimana ia bekerja siang malam agar jemaat tidak terbebani (1Tes 2: 9). Paulus juga mengungkapkan kepada jemaat dan Penatua di Efesus tangannya sendirilah yang memenuhi setiap kebutuhannya (Kis. 20: 34). Ia juga menyatakan kepada jemaat di Korintus bahwa ia tidak mempergunakan hakhaknya untuk meminta kepada jemaat karena sudah melayani mereka, walau hal itu lumrah sebagai seorang pemberita Injil (1Kor. 9: 15). Silalahi mengemukakan prinsip hidup rasul Paulus dalam melayani berbeda dari rasul yang lain. Perbedaan itu dapat dilihat melalui komitmen Paulus yang tidak membebankan urusan finansial kepada jemaat yang dirintisnya. Paulus menekankan komitmennya agar tidak mengharapkan upah atas pelayanan yang dilakukannya walau sebenarnya 
berhak untuk itu. Alasan Paulus tidak mengharapkan imbalan dari jemaat yang dirintisnya karena pemberitaan Injil yang dilakukan adalah anugrah dari Allah, karena itu Paulus lebih memilih bekerja untuk penghidupannya. ${ }^{46}$ Dengan demikian tidak berfokus pada hal materi ketika memulai perintisan gereja menunjukkan pribadi hamba Tuhan yang mengerti panggilan Allah, sebagai seorang hamba yang melaksakan tugas yang didelegasikan. Tidak berfokus pada meteri ketika merintis gereja juga menunjukkan hamba Tuhan memahami segmentasi jemaat yang dilayani adalah para petobat baru yang membutuhkan pengajaran firman Allah.

\section{KESIMPULAN}

Penulis menarik kesimpulan bahwa masih banyak suku-suku yang terabaikan di Indonesia, berdasarkan data IPN dari 781 suku yang ada di Indonesia, sebanyak 131 suku dengan jumlah 142.000 .000 jiwa yang belum terjangkau oleh Injil. Perintisan gereja-gereja pada saat ini masih cenderung banyak terjadi di kota-kota, sehingga perlu pelaksanaan Amanat Agung untuk menjangkau pelosok-pelosok atau desa-desa di Indonesia. Untuk mendukung terciptanya gerakan perintisan gereja perlu kontribusi organisasi gereja dan seminari teologi dalam menyiapkan calon perintis gereja melalui kaderisasi, sementara seminari memperlengkapi para calon hamba Tuhan dalam pelayanan. Ini diperlukan agar pengimplementasian Amanat Agung dengan cara merealisasikan perintisan gereja yang bertujuan meluaskan berita Injil dan makin bertambahnya secara kuantitas orang percaya.

46 Junior Natan Silalahi, "Paulus Sang Entrepreneur: Pembuat Tenda Sebagai Jembatan Penginjilan," Visio Dei: Jurnal Teologi Kristen 1, no. 1 (2019): 2-3. https://doi.org/10.35909/visiodei.v1i1.9 


\section{KEPUSTAKAAN}

Albert Konaniah. "Sekolah Teologi Dan Gerakan Penginjilan.” Veritas : Jurnal Teologi dan Pelayanan 3, no. 2 (2002). https://doi.org/10.36421/veritas.v3i2.94

Bernard Adeney-Risakotta. "Mengkritisi Peran Pendidikan Teologia Dalam Pengembangan Teologi Protestan Di Indonesia." Gema Teologi 3, no. 1 (2009).

Donald Guthrie. Tafsiran Alkitab Masa Kini 3 Matius-Wahyu. Disunting oleh A. Simanjuntak. 12 ed. Jakarta: Yayasan Komunikasi Bina Kasih/OMF, 2001.

Eklepinus Jefry Sopacuaperu. "Misi Rekonsiliasi Dalam Konteks Kemajemukan Agama Di Indonesia (Analisis Naratif Yohanes 20:19-23 Dan Implikasi Misiologisnya)." Kenosis 6, no. 1 (2020). https://doi.org/10.37196/kenosis.v6i1.85

Fransiskus Irwan Widjaja, Daniel Ginting \& Sabar Manahan Hutagalu. "Teologi Misi sebagai Teologi Amanat Agung." Thronos 1, no. 1 (2019).

Fransiskus Irwan Widjaja, Selvyen Sophia, Otieli Harefa, dan Rini Sumanti. "Motif Misi Dan Pertumbuhan Gereja Masa Kini." Real Didache 3, no. 2 (2018): 23. https://doi.org/10.13140/RG.2.2.34081.63849.

George W. Peters. A Biblical Theology of Missions. 1 ed. Malang: Gandum Mas, 2006.

"Gerakan-gerakan Pendirian Jemaat - Perspektif: Tentang Gerakan Orang Kristen Dunia." Diakses 18 Februari 2021. https://perspektif.co/Gerakangerakan_Pendirian_Jemaat.

H, D. Perintisan Gereja, 15 Februari 2021.

Handi Irawan \& Bambang Budijanto. Kunci Pertumbuhan Gereja Berdasarkan Temuan Survei Nasional BRC. Jakarta: Yayasan Bilangan Research Center, 2020. http://bilanganresearch.com/hasil-penelitian.html

Hidajat, Djeffry. "Sejarah dan Perkembangannya Masa Kini dan Arah Masa Depan." Jurnal Amanat Agung, t.t.

Hutabarat, Binsar A. "Evaluasi Terhadap Peraturan Bersama Menteri Tahun 2006 Tentang Pendirian Rumah Ibada." Societas Dei 4, no. 1 (2017). https://doi.org/10.33550/sd.v4i1.41

Ihsan Ali-Fauzi, Samsu Rizal Panggabean, Nathanael Gratias Sumaktoyo, Anick H. T., Husni Mubarak, Testriono, dan Siti Nurhayati. Kontroversi Gereja di Jakarta. Jakarta: Universitas Gadjah Mada, 2011. 
Imeldawati, Tiur. "Manajemen Perguruan Tinggi Teologi." Jurnal Teologi dan Pendidikan Agama Kristen 1, no. 1 (2019).

J. I. Packer. Penginjilan Dan Kedaulatan Allah Evangelism And The Sovereignty Of God. Surabaya: Momentum, 2003.

Junior Natan Silalahi. "Paulus Sang Entrepreneur: Pembuat Tenda Sebagai Jembatan Penginjilan." Visio Dei: Jurnal Teologi Kristen 1, no. 1 (2019). https://doi.org/10.35909/visiodei.v1i1.9

Larry Pate. Merintis Gereja-Gereja Baru. Malang: Gandum Mas, 1984.

M Chairul Basrun Umanailo. Ilmu Sosial Budaya Dasar. Jakarta: Fam Publishing, 2015.

Michael J. Anthony. Foundaion Of Mnistry An Introduction Christian Education For A New Generation. Disunting oleh Christian A Tomatala. Malang: Gandum Mas, 2012.

Mills, Dag Heward. Perintis Gereja. Disunting oleh Daniel Benjamin Saragih. EBOOKS. Parchment House, 2014.

Nikodemus Thomas Martoredjo. "Peran Dimensi Mentoring Dalam Upaya Peningkatan Kualitas Sumber Daya Manusia.” Humaniora 6, no. 4 (2015). https://doi.org/10.21512/humaniora.v6i4.3373

Paul Barnett. The Birth of Christianity. Disunting oleh M Rumkeny. I. Malang: Gandum Mas, 2012.

Paul Enns. The Moody Hanbook Of Theology. Malang: SAAT, 2010.

Prihanto, Agus. "Peran Proses Mentoring Pemimpin Kaum Muda Bagi Perkembangan Pelayanan Pemuda Di Gereja." Jurnal Jaffray 16, no. 2 (2018). http://dx.doi.org/10.25278/jj71.v16i2.258

Purdaryanto, Samuel. "Strategi Melayani Unreached People Groups Berdasarkan Kajian Eksegetis 1Korintus 9: 19-23." Manna Rafflesia 6, no. 2 (2020): 178-99. https://doi.org/10.38091/man_raf.v6i2.122

Rick Warren. The Purpose Driven Church. Malang: Gandum Mas, 2004.

Roedy Silitonga. "Amanat Agung Dan Kemajemukan Agama: Suatu Refleksi." Stulos 16, no. 1 (2018).

Rombe, Agustina. "Pengaruh Pelayanan Diakonia terhadap Pertumbuhan Gereja Toraja Jemaat Sudiang Makassar." Sekolah Tinggi Theologia Jaffray, 2018. 
Saprillah, Saprillah. "Rumah Ibadah Sebagai Medan Kontestasi Beragama." Harmoni $16, \quad$ no. 2018 : https://doi.org/10.32488/harmoni.v16i2.13.

Simon. "Fenomena Social Climber Ditinjau Dari Perspektif Etika Kristen." Fidei: Jurnal Teologi Sistematika Dan Praktika 2, no. 2 (2019). https://doi.org/10.34081/fidei.v2i2.55

_. "Peran Roh Kudus Bagi Hamba Tuhan Dalam Merintis Gereja." LOGIA: Jurnal Teologi Pentakosta 1, no. 2 (2020). https://doi.org/10.37731/log.v1i2.33

Sugiyono. Statistika Untuk Penelitian. Bandung: Alfabeta, 2014.

Supriadi, Made Nopen. "Implikasi Relasi Sekolah Tinggi Teologi Arastamar Bengkulu Bagi Pengembangan Pelayanan Misi Gereja Kristen Injili Di Indonesia Jemaat Kota Bengkulu." Jurnal PKM Setiadharma 1, no. 2 (2020): 1-12. https://doi.org/10.47457/jps.v1i2.54

Warren, Rick. The Purpose Driven Church, Gereja yang digerakkan oleh Tujuan. Malang: Gandum Mas, 2001.

Yan Antoni. "Amanat Agung Belum Selesai Matius 28:18-20; Lukas 24:46-47." Jurnal Amanat Agung 7, no. 1 (2011).

Zed, Mestika. Metode Penlitian Kepustakaan. Jakarta: Yayasan Obor Indonesia, 2008. 